\title{
新規グリセリド誘導体による経皮吸収促進効果と 機構に関する研究
}

\author{
大阪大学薬学部 \\ ○久保一義、東條伸輝、余蔚、小比賀聡、今西武、真弓忠範
TRANSDERMAL PENETRATION-ENHANCING EFFECT AND ITS MECHANISM OF NOVEL TRIGLYCERIDES HAVING QUATERNARY AMMONIUM GROUP

Kazuyoshi KUBO, Nobuteru TOJYO, Wei YU, Satoshi OBIKA, Takeshi IMANISHI and Tadanori MAYUMI

Faculty of Pharmaceutical Sciences, Osaka University, Suita, Osaka 565

【目的】医薬品の多くは弱電解質であり、生理的 $\mathrm{pH}$ 条件下において、その一部または大 部分がイオン化して存在するため皮膚透過性は一般に低い。この場合、薬物と反対符号の 電荷を持つイオン種（カウンターイオン）とイオン対を形成させることにより、薬物の皮 膚移行性を促進し皮膚透過性を改善することができる1)。

脂溶性のイオン対を利用する経皮吸収促進の方法は、目的とする薬物に応じて最も有効 なカウンターイオンの選択が可能であり、吸収部位に一定量のイオン対を適用できるため、 促進効果を定量的に評価できる利点を有する。

しかしこの方法では、目的とする薬物と共にカウンターイオンも皮膚に分配するため、 その皮膚刺激性や毒性などの副作用を考慮しなければならない。

我々は、有効で安全性の高いカウンターイオンを開発するため、角質層脂質や皮脂の構 成成分であるトリグリセリドに着目し、近年、経皮吸収促進剂開発の手法として注目され ている” soft”ドラッグアプローチ2)を応用して、四級アンモニウム構造を有する生体分解 性グリセリド誘導体（以下YKS）を合成した。モデル酸性薬物として、サリチル酸および クロモグリク酸を用いYKSとのイオン対形成によるラット皮膚透過促進、吸収促進剂適用 とイオン対の組合わせによる皮膚透過促進効果、YKSの皮膚刺激性について検討した。

【方法】1)使用薬物 YKSは、グリセロールアセトニドを出発原料としてRCOClでアシル 化したジアシルモノクロロアセチルグリセロールを経由して合成したR=C2H5〜C7H15の 化合物を使用した。（Scheme 1)

2) 盀 vitro皮盧透過実験ａ）Wistar系雄性ラット（5-6週令）の腹部を除毛後、摘出皮膚を $32^{\circ} \mathrm{C}$ に保ったフランツ型拡散セル（有効面積 $1.73 \mathrm{~cm}^{2}$ ) に挟み、真皮側（レセブター側） に生理食塩水 $10.5 \mathrm{ml}$ 、角質層側（ドナー側）に1/30 M酢酸緩衝液( $\mathrm{pH} 5.0$ )に溶解した酸性薬 物(0.8 mM)1 mlを加えた。YKSとのイオン対の影響をみる場合は、酸性薬物に対し2.5-10倍 量のYKSを溶解した溶液 $1 \mathrm{ml}$ 加えた。レセブター溶液はマグネチックスターラーで䚌拌 
し透過実験を行った。 レセプター側から経 時的にサンプリングし、 定量はHPLCで行った。 サンプリングによる減 少分は新しい生理食塩 水で補った。

b) 吸収促進剂による前 処置の実験では、ラッ ト腹部摘出皮膚をフラ

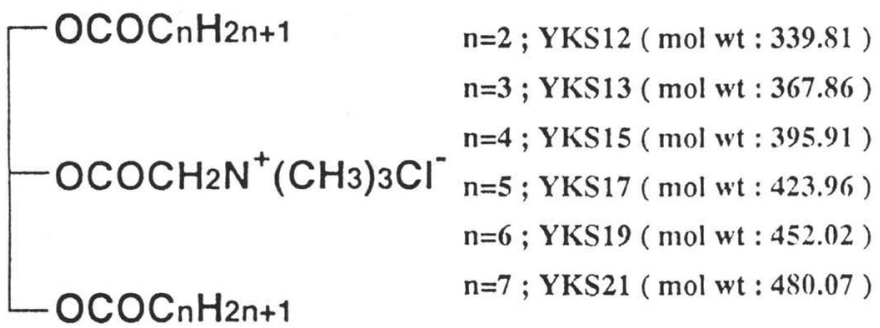

\section{Scheme 1 Chemical structures of YKS}

ンツ型拡散セルに装着後、吸収促進剂のエタノール溶液 $0.1 \mathrm{ml}$ 加え24時間前処置を行った。 その後、ドナー側をエタノールで洗浄し吸収促進剤を除いた後、a)と同様の方法で薬物溶 液またはイオン対溶液を適用して透過実験を行った。

3)YKSの皮膚刺激性 試料溶液は3.0\%及び5.2\%YKS21エタノール溶液、溶媒対照物質とし てエタノール、対照物質として $1.0 \%$ 及び $3.0 \%$ Azoneエタノール溶液を用いた。前日に除毛 したウサギの背部皮膚に、動物用バッチテスト用絆創高（直径 $2.5 \mathrm{~cm}$ のンント布）に投与試 料0.25 mlを均一に湿らせ適用した。試料投与後の皮膚の観察は、Draizeらの方法 ${ }^{3)}$ およ゙ その変法 ${ }^{4)}$ に準拠して行った。

【結果と考察】1)YKSの構造と安定性 合成したグリセリド誘導体、YKS12-YKS21は、生 理的pHで常にイオン型として存在する四級アンモニウム構造と、脂溶性を調節するための アルキル鎖及び生体分解性のエステル結合を分子中に含む(Scheme 1)。YKSは、pH4-pH7、 $32^{\circ} \mathrm{C}$ において一次速度的に分解し、 $\mathrm{pH} 7.0$ における半減期は約4.5時間、弱酸性側では分解 は抑制され、24時間以上にわたって安定であった。またこの分解は、アンモニウム残基の ついたエステル部位の加水分解であることをNMR測定により確認している。これらの結果 から、以後の実験はYKSが安定な弱酸性条件下で行った。

皮膚表面はpH4.2-5.6であり、生きた表皮以下の層ではpH7.4付近であることから、YKS は経皮吸収促進のターゲット組織である角質層では安定に作用を発現し、皮膚深部への拡 散にともない代謝酵素の作用も加わり分解していく可能性が示唆された。

2)モデル酸性薬物の油水分配係数におよぼすYKSの影響 使用した一価アニオンのサリチ ル酸、二価アニオンのクロモグリク酸は、ともにYKSとイオン対を形成しオクタノールヘ の分配が促進された。YKSのアルキル鎖長の増加に伴い、顕著なみかけの油水分配係数 (APC)の増加が見られた。

3)In vitro皮膚透過性におよぼすYKSの影響 サリチル酸 $(0.5 \mathrm{mM})$ のin vitro皮膚透過性は、 YKS添加により有意に促進され、透過速度、透過係数はコントロールに比較してYKS17(5 $\mathrm{mM})$ で約2.5倍、YKS19(5 mM)で約8倍増加した。ラグタイムは、コントロールと比較して 有意差はないかまたは遅延することから、透過速度、透過係数の増加はYKSとサリチル酸 のイオン対形成による皮膚/基剤間分配係数の増加に起因するものと考えた。このことは、 YKS19(5 mM)とイオン対を形成しないカチオン性薬物プロプラノロール $(1 \mathrm{mM})$ に対して、 
その促進効果は低く、透過 速度及びラグタイムに有意 差は認められなかったこと からむ確認された。クロモ グリク酸( $0.8 \mathrm{mM})$ のラット 皮膚透過性は、YKS21 (2 m $\mathrm{M})$ 添加により有意に促進さ れサリチル酸の場合と同様 にYKS21がカウンターイオ ンとして有用であることが 示された (Fig. 1)。

4)YKSの吸収促進唷としての有用性

クロモグリク酸のin vitro皮膚透 過性は、YKS21の濃度依存的に促 進され、3.0\% YKS21前処置では、 無処置コントロール(NP)及びエタ ノール前処置(EP) と比較して、そ れぞれ約6倍、約2倍の促進効果が 認められた。無処置(NP)及びエタ ノール前処置(EP) と比較して、ラ グタイムが顕著に短縮されている ことから、この促進効果は、

YKS21前処置による皮膚の拡散性 改善に起因するものと考えられた

(Fig. 2)。YKSとイオン対を形 成しないプロプラノロールに対し ても、3.0\% YKS21前処置により同 様な促進効果が認められた。これ らのことから、YKS21はカウンタ ーイオンとしてだけでなく、経皮 吸収促進剂としても有用であるこ とが示唆された。

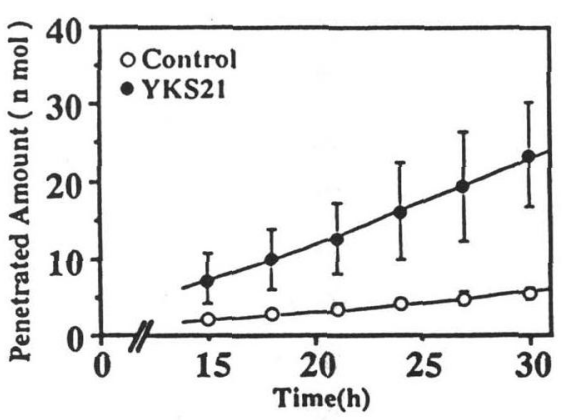

\begin{tabular}{cccc}
\hline Counter ion & $\mathrm{J}\left(\times 10^{-9} \mathrm{mo} / \mathrm{h} / \mathrm{cm}^{2}\right)$ & $\mathrm{Kp}\left(\times 10^{-3} \mathrm{~cm} / \mathrm{h}\right)$ & $\mathrm{LT}(\mathrm{h})$ \\
\hline Control & $0.130 \pm 0.019$ & $0.163 \pm 0.024$ & $5.57 \pm 0.88$ \\
YKS21 & $0.622 \pm 0.157^{* *}$ & $4.44 \pm 1.12^{* *}$ & $8.99 \pm 1.61^{*}$ \\
\hline
\end{tabular}

Fig. 1 Effect of YKS21 on penetration of cromoglicate through rat skin at $32^{\circ} \mathrm{C}$

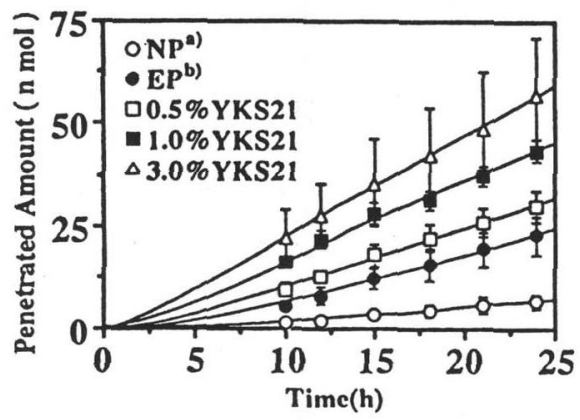

\begin{tabular}{cccc}
\hline Enhancer & $J\left(\times 10^{-9} \mathrm{~mol} / \mathrm{h} / \mathrm{cm}^{2}\right)$ & $K p\left(\times 10^{-3} \mathrm{~cm} / \mathrm{h}\right)$ & $\mathrm{LT}(\mathrm{h})$ \\
\hline NP & $0.227 \pm 0.060$ & $0.284 \pm 0.075$ & $6.71 \pm 0.50$ \\
EP & $0.717 \pm 0.133$ & $0.896 \pm 0.166$ & $5.46 \pm 0.47$ \\
$0.5 \%$ YKS21 & $0.840 \pm 0.104$ & $1.05 \pm 0.13$ & $3.09 \pm 0.32^{* * *}$ \\
$1.0 \%$ YKS21 & $1.22 \pm 0.00^{* *}$ & $1.53 \pm 0.02^{* *}$ & $2.03 \pm 0.61^{* *}$ \\
$3.0 \%$ YKS21 & $1.42 \pm 0.34^{*}$ & $1.78 \pm 0.42^{*}$ & $1.03 \pm 0.95^{* *}$ \\
\hline
\end{tabular}

Fig. 2 Effect of pretreatment on penetration of cromoglicate through rat skin at $32^{\circ} \mathrm{C}$

5)経皮吸収促進剂適用とイオン対形成の組み合わせによる経皮吸収促進 YKSをカウンタ 一イオンとして用いた場合、イオン対形成により皮膚への分配性が改善されたこと、また YKSの前処置により皮膚の拡散性が改善されたことから、その作用機構が異なることを明 らかにした。次に、これらの組合わせによる透過促進効果について検討した。3\% $\% \mathrm{YS}$ 前処 置後、ドナーセルにクロモグリク酸 $(0.8 \mathrm{mM})$ とYKS21(2 mM)を加えて（以下、イオン対を 適用したと表現する）in vitro皮膚透過実験を行った結果、無処置皮膚にイオン対を適応し た場合、又は3\% YKS21前処置後クロモグリク酸のみで適用した場合に比較して有意に透過 
性が改善された(Fig. 3)。イオン 対形成のみ、および経皮吸収促 進剤のみの場合と比較して両者 の組合わせは有用であり、より 強い透過促進が期待できること が分かった。ちなみに、3\% YKS21前処置後イオン対を適用 した場合、1\%Azoneに近い促進 効果が得られた。また、前処置 時間について検討した結果、

Azoneは、最大効果の発現に24時 間を要するのに対し、YKS21の 場合、2時間以内の前処置で十分 であることが明らかになった。 短時間での効果発現は実用化の

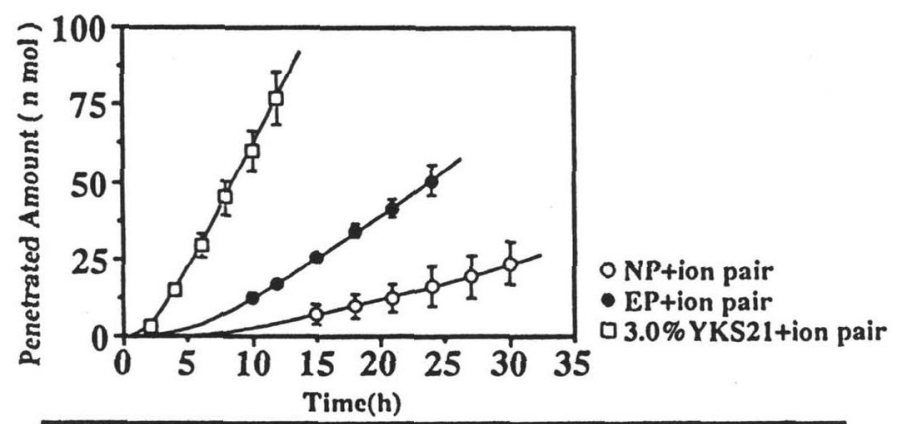

\begin{tabular}{cccl}
\hline Enhancer & $\mathrm{J}\left(\times 10^{-9} \mathrm{molh} / \mathrm{cm}^{2}\right)$ & $\mathrm{Kp}\left(\times 10^{-3} \mathrm{~cm} / \mathrm{h}\right)$ & $\mathrm{LT}(\mathrm{h})$ \\
\hline $\mathrm{NP}$ & $0.622 \pm 0.157$ & $4.44 \pm 1.12$ & $8.99 \pm 1.61$ \\
EP & $1.57 \pm 0.18^{* *}$ & $11.2 \pm 1.3^{* *}$ & $5.50 \pm 0.73^{*}$ \\
$3.0 \% \mathrm{KS} 21$ & $4.31 \pm 0.50^{* *}$ & $30.8 \pm 3.6^{* *}$ & $1.86 \pm 0.14^{* *}$ \\
\hline
\end{tabular}

Fig. 3 Combination effect of pretreatment and Ion-pair formation on penetration of cromoglicate through rat skin at $32^{\circ} \mathrm{C}$ 面でも有利であると考えられる。

6)YKSの皮虚刺激性一次刺激指数から、YKS21は皮膚刺激性が弱く、Azoneと比較して35倍安全であることが判明した。これは24時間投与後の判定結果であるが、YKS21は2時間 以内で最大の効果を発現することから、Azoneと比較して、さらに刺激性を軽減できると考 えられる。また、YKS21は紅斑と浮腫の回復性においても優れていた。

【ABSTRACT】 Novel biodegradable triglycerides having quaternary ammonium group (YKS) were synthesized as counter ions for ion-pair complexation with anionic drugs and evaluated for their transdermal penetration enhancing effects. Permeation of salicylate or cromoglicate, model anionic drugs, through the rat skin were measured in modified Franz-type diffusion cells. The steady-state flux, the permeability coefficient and the diffusion coefficient were calculated. The permeability of these anionic drugs were enhanced by an ion-pair mechanism in the presence of the YKS. Significant increases in the permeability parameters were observed after pretreatment with YKS. It was shown that YKS21 itself was an excellent penetration enhancer as well as an effective counter ion for ion-pair transport. The exact mechanisms of the increased permeability by pretreatment with YKS remain to be elucidated. When ion-pair complex of cromoglicate with YKS21 was applied in the donor compartment after pretreatment with 3\% YKS21 for 24 hours, it was found that this ion-pair complex with the pretreatment was several times more effective than cromoglicate applied alone with the pretreatment or than ion-pair complex without the pretreatment. Judging from the primary irritation indices, YKS21 was 3 to 5 safer than Azone.

\section{【REFERENCES】}

1) R. Neubert, Pharm. Res., 6, 743-747 (1989).

Chul-Soon Young, et al., Int. J. Pharmaceut., 45, 59-64 (1988).

T. Ogiso, et al., J. Pharm. Sci., 79, 1065-1071 (1990).

2) W. J. Lambert, et al., Int. J. Pharm., 95, 181-192 (1993).

3) J. H. Draize, et al., J. Pharmacol. Exp. Ther., 82, 377-390 (1944).

4) 池田良雄ら、医薬品研究、1, 23-27 (1970).

青柳繁、実験動物技術、23, 5-10 (1988). 